\title{
Spububsaúde
}

\section{Glycemic index of foods: A review}

\author{
Índice glicêmico dos alimentos: Uma revisão
}

\author{
Pedro Henrique Silva de Rossi" ${ }^{\circ}$, Sandra Maria Barbalho ${ }^{\circ}$, Marie Oshiiwa ${ }^{\circ}$, Andressa Aparecida \\ Jacinto Sampaio ${ }^{\circ}$
}

Faculdade de Tecnologia de Marília, Marília, São Paulo, Brasil. *Autor para correspondência: E-mail: pps.2010.ph@gmail.com

\begin{abstract}
One of the tools to help in the treatment of diseases is the index and glycemic load of food. The objective of the work is to carry out data survey in the literature about the influence of the glycemic indicator of foods. Databases such as MEDLINE / Pubmed, Scielo and Google Scholar were consulted. There is a trend of nutritional change due to urbanization and industrialization that lead to a more westernized diet, related to increased density, with greater consumption of meat, milk and fat-rich derivatives, and reduced consumption of fruits and vegetables. Foods with a high glycemic index induce an increase in glycemia of up to twice as much as foods with a low glycemic index, which may result in the appearance or worsening of several chronic diseases. Understanding the glycemic index of foods is essential for dietary planning and glycemic control.
\end{abstract}

Keywords: glicemic, food, health.

Resumo: Uma das ferramentas para auxiliar no tratamento de doenças é o índice e a carga glicêmica dos alimentos. O objetivo deste trabalho é realizar levantamento de dados na literatura sobre a influência do indicie glicêmico dos alimentos. Bancos de dados como MEDLINE / Pubmed, Scielo e Google Scholar foram consultados. Existe uma tendência de mudança nutricional devido da urbanização e industrialização que direcionam para uma dieta mais ocidentalizada, com relevância para o aumento da densidade energética, com maior consumo de carnes, leite e derivados ricos em gorduras, e redução do consumo de frutas e verduras. Os alimentos com alto índice glicêmico induzem a um aumento na glicemia de até duas vezes mais do que os alimentos de baixo índice glicêmico, podendo resultar no surgimento ou agravamento de diversas doenças crônicas. A compreensão do índice glicêmico dos alimentos é fundamental para o planejamento dietético e controle glicêmico.

Palavras-chave: glicemia, alimentos, saúde.

\section{Introduction}

Studies prove the importance of good eating habits to prevent emergence of chronic diseases. Fiber-rich foods are widely used in the prevention of these pathologies (Santos, 2017).

According to Mariath (2007), there was an increase in the accumulation of body fat, favoring a greater deposit of this fat in the abdominal region, characterizing obesity, which is relevant as a risk factor for the appearance of chronic non transmissible disease, such as hypertension, dyslipidemias, diabetes that is somewhat characterized by a latency period, prolonged evolution time and irreversible lesions that, when not leading to death, cause various levels of disability.

Also according to Mendonça (2005), obesity is characterized by the accumulation of the negative energy balance, relating not only to the quality of life, but also the quantity

The prevalence of chronic diseases has increased worldwide in recent years, and initiates a series of metabolic changes that worsen human health. Among these, the eating behavior of the population stands out. The evaluations indicate a higher consumption of simple carbohydrates, which directly correlates with the disorder of glucose metabolism, characterized by elevated fasting glucose (Lim, 2009).

Dietary carbohydrates exist in a variety of plant derived foods, and these foods are the most abundant food sources in nature. In terms of types and amounts of carbohydrates, differences in the composition of plant foods should attract special attention from different researchers to characterize their effects on satiety, blood sugar control, body weight and blood lipid levels, which are essential for maintain health important (Kristensen, 2010). 
Several studies have emphasized that, in addition to better control of the treatment of diabetes, the reduction of the food response to glucose is also related to the reduction of the risk of diabetes and cardiovascular diseases (Iannuzzi, 2009).

Throughout the research on the glycemic index of foods, several authors have known the glycemic load, emphasizing that this is a new measure of the quality and quantity of carbohydrates in the food obtained from the glicemic index and total carbohydrates index. In the food. These data have a more practical application and can be used to calculate the diet, as they can indicate the blood glucose response that a particular food or diet may cause (Krisshnan, 2007).

The glicemic load of foods deals with the relationship between the quality of carbohydrates expressed in glicemic index and the amount of total carbohydrates in the food consumed. Glicemic load may have a more practical application in dietary prescriptions, although it is rarely implemented (Sampaio, 2010).

\section{Methods}

Data bases such as MEDLINE/Pubmed, Scielo, and Google Scholar were consulted.

\section{Results and discussion}

It is important to know the glycemic index of the carbohydrates to be injected and the different types of food, as the best choice may not only be reflected in the glucose response, but also not only for patients with glucose uptake dysfunction, but also for treatment diabetes patient (Winham, 2017).

The Glycemic Index also constitutes applicable tool for the practitioner of physical activity, due to the type of carbohydrate and the period of intake influence in the correct replenishment of carbohydrate, since, sharp drops in the concentration of muscle glycogen lead fatigue and consequently drop in performance (Siqueira, 2007).

\section{Sugar Level}

Developed by Jenkins in the early 1980s, the concept of the Glycemic Index is one of the quantitative methods for describing the quality of carbohydrates based on the glycemic response.

Considering the effective intention of these foods, their frequent use is necessary, the main sources are fruits, vegetables, whole grains, meats, soy milk and foods rich in omega 3 . The functions of foods are: carotenoids, flavonoids, fatty acids such as omega 3, prebiotics (oligofructose and inulin), probiotics, fibers, among others. (Marques, 2019).

Among the different dietary strategies, probiotic interventions are gaining more and more attention in the scientific community, mainly for their ability to bring health benefits. They are clearly defined as "living microorganisms" and when administered in sufficient quantities, they can benefit the health of the host (Khalesi, 2017).

According to Cardoso (2017), fibers are classified according to their solubility in water, which can be soluble or insoluble. The purpose of the soluble fiber is to prolong the intestinal transit time, reducing gastric emptying and delaying the absorption of glucose. For insoluble fiber, it will help in the formation of stool cake and delay the decomposition of starch. However, these insoluble fibers have no direct effect on reducing glucose.

\section{Benefits and concept for functional foods}

Barbosa et al. (2017) observed that the majority of respondents mentioned the use of natural resources as a treatment or adjuvant in their research, the most reported being plant species. In addition to a very old practice among the world population, the use of medicinal plants is a more easily available source than other medicines and also helps to reduce blood sugar.

In the work of Salehie's collaborators (2019), it was found that traditional medicinal plants are effective. Several plants have been reported to have anti-diabetic, anti-hyperglycemic and hypoglycemic activities and eaten effects on glucosidase. The antidiabetic effect of plants is attributed to the mixture of phytochemicals or compounds in plant extracts. The main phytochemicals responsible for the effects of antidiabetics are: alkaloids, phenolic acids, flavonoids, glycosides, saponins, polysaccharides, stilbenes, tannins.

According to Oliveira \& Manfrinato (2018) the preparation of pasta with oatmeal is justified for the improvement of the nutritional value of the product, in which it was evidenced the occurrence of a significant increase in the fiber content and decrease in the glycemic index, consequently making the food 
healthier. This occurs mainly when linked to the issues where a special diet is needed that requires a little more fiber to lower blood glucose.

The study by Li et al. (2016), showed that a low-fat, high-fiber diet had beneficial effects on glycolipid metabolism in overweight patients, and these effects were more evident when combined with oat intake. Thus evidencing that this food can be a good ally in the control of excess weight and, mainly in the reduction of glycemic levels.

Santiago et al. (2017) reported that diet cookies added to passion fruit peel flour had nutritional value, in addition to low energy value and dietary fiber such as pectin in passion fruit peel, also emphasized high content of minerals and proteins.

Robert et al. (2016) showed that the use of fenugreek seeds instead of $10 \%$ refined wheat flour can significantly reduce the blood sugar response and the blood sugar index of bread. Therefore, fenugreek powder is considered an effective functional ingredient for lowering blood sugar.

\section{Conclusion}

From what has been disclosed, the interest of researchers in studying the relationship between certain chemical components of food and the improvement of blood sugar is undeniable, and the amount of evidence is increasing.

Through this study, it can be concluded that in addition to healthy eating, functional foods in the diet can also reduce the risk of disease and assist in the treatment of diseases.

\section{References}

Barbosa, M. A. G., Almeida, A. M. R., Figueiredo, M. A., Negromonte, A. G., da Silva, J. S. L., Viana, M. G. S., \& Galvão, G. K. C. 2015. Alimentação e diabetes mellitus: percepção e consumo alimentar de idosos no interior de Pernambuco. Revista Brasileira em promoção da Saúde, 28(3), 370-378.

Cardoso, H. C. S. 2017. Nutrição funcional e seu envolvimento no Diabetes Mellitus tipo 2. Trabalho de conclusão de curso (Nutrição). Brasília, DF: Centro Universitário de Brasília - Uni CEUB.

Iannuzzi, A., Licenziati, M. R., Vacca, M., De Marco, D., Cinquegrana, G., Laccetti, M., ... \& Parillo, M. 2009. Comparison of two diets of varying glycemic index on carotid subclinical atherosclerosis in obese children. Heart and Vessels, 24(6), 419.

Jenkins, D. J., Kendall, C. W., Augustin, L. S., Franceschi, S., Hamidi, M., Marchie, A., ... \& Axelsen, M. 2002. Glycemic index: overview of implications in health and disease. The American Journal of Clinical Nutrition, 76(1), 266S-273S.

Khalesi, S., Bellissimo, N., Vandelanotte, C., Williams, S., Stanley, D., \& Irwin, C. 2019. A review of probiotic supplementation in healthy adults: helpful or hype?. European Journal of Clinical Nutrition, 73(1), 24-37.

Krishnan, S., Rosenberg, L., Singer, M., Hu, F. B., Djoussé, L., Cupples, L. A., \& Palmer, J. R. 2007. Glycemic index, glycemic load, and cereal fiber intake and risk of type 2 diabetes in US black women. Archives of Internal Medicine, 167(21), 2304-2309.

Kristensen, M., Jensen, M. G., Riboldi, G., Petronio, M., Bügel, S., Toubro, S., ... \& Astrup, A. 2010. Wholegrain vs. refined wheat bread and pasta. Effect on postprandial glycemia, appetite, and subsequent ad libitum energy intake in young healthy adults. Appetite, 54(1), 163-169.

Lim, H. M., Park, J. E., Choi, Y. J., Huh, K. B., \& Kim, W. Y. 2009. Individualized diabetes nutrition education improves compliance with diet prescription. Nutrition Research and Practice, 3(4), 315-322.

Mariath, A. B., Grillo, L. P., Silva, R. O. D., Schmitz, P., Campos, I. C. D., Medina, J. R. P., \& Kruger, R. M. (2007). Obesidade e fatores de risco para o desenvolvimento de doenças crônicas não transmissíveis entre usuários de unidade de alimentação e nutrição. Cadernos de Saúde Pública, 23, 897-905.

Marques, C. G., Alves, R. T., Lee, C. J. Y. P., \& dos Santos Quaresma, M. V. L. 2019. Efeito do consumo de Kefir sobre parâmetros bioquímicos relacionados ao Diabetes Mellitus: uma revisão de literatura. Revista Eletrônica Acervo Saúde, 19, e214-e214.

Oliveira, S., \& Manfrinato, C. B. 2018. Desenvolvimento de macarrão a base de farinha de aveia para portadores de diabetes. Revista Uningá, 37.

Robert, S. D., Ismail, A. A., \& Rosli, W. I. 2016. Reduction of postprandial blood glucose in healthy subjects by buns and flatbreads incorporated with fenugreek seed powder. European Journal of Nutrition, 55(7), $2275-2280$. 
Salehi, B., Ata, A., V Anil Kumar, N., Sharopov, F., Ramírez-Alarcón, K., Ruiz-Ortega, A., ... \& Iriti, M. 2019. Antidiabetic potential of medicinal plants and their active components. Biomolecules, 9(10), 551.

Sampaio, H. A. D. C., Silva, B. Y. D. C., Sabry, M. O. D., \& Almeida, P. C. D. 2007. Índice glicêmico e carga glicêmica de dietas consumidas por indivíduos obesos. Revista de Nutrição, 20(6), 615-624.

Santiago, A. D. B. R., Silva, J. A. D., Conceição, M. L. D., \& Aquino, J. D. S. 2016. Qualidade de biscoitos diet adicionados de farinhada casca do maracujá avaliados sensorialmente por diabéticos. Mundo Saúde (Impr.), 362-371.

Santos, M., dos Santos, A. V., \& Costa, E. S. 2017. Efeito dos compostos solúveis em água de quiabo (Abelmoschus esculentus L) nos níveis glicêmicos de camundongos Mus musculus. Ciência ET Praxis, 7(13), 07-10.

Siqueira, F. R., Rodrigues, F. L. P., \& Frutuoso, M. F. P. 2007. Índice Glicêmico como ferramenta de auxílio de prescrição de dietas. Revista Brasileira de Nutrição Clínica, 22, 54-8.

Winham, D. M., Hutchins, A. M., \& Thompson, S. V. (2017). Glycemic response to black beans and chickpeas as part of a rice meal: a randomized cross-over trial. Nutrients, 9(10), 1095.

Li, X., Cai, X., Ma, X., Jing, L., Gu, J., Bao, L., ... \& Li, Y. (2016). Short-and long-term effects of wholegrain oat intake on weight management and glucolipid metabolism in overweight type-2 diabetics: a randomized control trial. Nutrients, 8(9), 549.

\section{Minicurrículo}

Pedro Henrique Silva de Rossi. Graduando em Tecnologia em Alimentos pela Faculdade de Tecnologia de Marília.

Sandra Maria Barbalho. Possui Bacharelado em Ciências Biológicas pela Universidade Federal de São Carlos (1992); Licenciatura em Ciências Biológicas pela Universidade Federal de São Carlos (1991), Mestrado em Genética e Evolução pela Universidade Federal de São Carlos (1994) e Doutorado em Ciências pela Universidade Federal de São Carlos (1999). Atualmente é docente do Curso de Medicina da Universidade de Marília, UNIMAR. É integrante do Programa de Mestrado Acadêmico em Interações Estruturais e Funcionais na Reabilitação (UNIMAR). É membro do Comitê de Ética em Pesquisa em uso animal da UNIMAR. É professora de Bioquímica da Faculdade de Tecnologia em Alimentos de Marília (FATEC). Foi aprovada em primeiro lugar nos seguintes concursos: 1- Concurso Público para Educador na Área de Biologia Molecular Estrutural da Universidade de São Paulo (USP) Campus de São Carlos SP (Abril de 2001); 2- Concurso para professor de Bioquímica I e II da Faculdade Metodista de Piracicaba (UNIMEP) Campus de Lins SP (Junho de 2001); 3- Concurso Público para professor de Bioquímica da Faculdade de Tecnologia em Alimentos de Marília (Julho de 2007). Possui experiência em pesquisa e orientação na área Interdisciplinar envolvendo Bioquímica, Metabolismo, Plantas Medicinais e Alimentos Funcionais na Reabilitação da Saúde. Atua também como pesquisadora na área de metabolismo em doenças metabólicas (Síndrome Metabólica e Doenças Cardiovasculares). Possui 152 artigos publicados em periódicos (nacionais e internacionais). Participou de mais 80 bancas julgadoras. É autora de seis capítulos de livro (um nacional e 5 internacionais). Revisora de 28 periódicos internacionais. Total de citações no GOOGLE SCHOLAR: 1094, ÍNDICE H: 17 e ÍNDICE i10: 31.

Marie Oshiiwa. Possui graduação em Ciências com Habilitação Matemática pela Universidade de Marília (1987), Habilitação em Química pela Faculdade Auxilium de Filosofia Ciências e Letras de Lins (1995), mestrado em Agronomia (Energia na Agricultura) pela Universidade Estadual Paulista Júlio de Mesquita Filho (2001) e doutorado em Agronomia (Agricultura) pela Universidade Estadual Paulista Júlio de Mesquita Filho (2005). Atualmente é docente responsável pelas disciplinas de Estatística, Metodologia da Pesquisa Científica e Trabalho de Conclusão de Curso do curso de Tecnologia em Alimentos; membro do Corpo Editorial da Revista Alimentus e está na Coordenação do curso de pós-graduação Gestão em Controle de Qualidade dos Alimentos na FATEC de Marília. 
Andressa Aparecida Jacinto Sampaio. Graduanda em Tecnologia em Alimentos pela Faculdade de Tecnologia de Marília.

Como citar: Rossi, P.H.S., Barbalho, S.M., Oshiiwa, M., \& Sampaio, A.A.J. 2020. Glycemic index of foods: A review. Pubsaúde, 4, a072. DOI: https://dx.doi.org/10.31533/pubsaude4.a072

Recebido: 9 set. 2020.

Revisado e aceito: 16 set. 2020.

Conflito de interesse: os autores declaram, em relação aos produtos e companhias descritos nesse artigo, não ter interesses associativos, comerciais, de propriedade ou financeiros que representem conflito de interesse.

Licenciamento: Este artigo é publicado na modalidade Acesso Aberto sob a licença Creative Commons Atribuição 4.0 (CC-BY 4.0). 